Gut, 1971, 12, 783-788

\title{
Neural crest origin of the endocrine polypeptide (APUD) cells of the gastrointestinal tract and pancreas
}

\author{
A. G. E. PEARSE AND JULIA M. POLAK \\ From the Department of Histochemistry, Royal Postgraduate Medical School, Hammersmith Hospital, London
}

SUMMARY A method of labelling known to be appropriate for the demonstration of endocrine polypeptide (APUD) cells was found to label the cells of the neural crest in the chick embryo after as little as 72 hours' development. The method depends on the production, from an exogenous precursor, of an amine which is stored in specific granules and which is convertible by treatment with hot formaldehyde vapour into a fluorescent derivative. The whole technique is described as APUD-FIF.

The application of APUD-FIF to mouse embryos shows that at the 7-8 somite stage (eight days) labelled neural crest cells migrate in large masses in a ventrad direction. At around the ninth day they colonize the developing foregut and its derivatives, including pharynx, stomach, duodenum, ultimobranchial body, and pancreas. In subsequent stages of development (up to 12 days) the cells are seen in comparatively large numbers in the gastrointestinal tract and in the pancreas.

Complete proof that these early APUD cells, which demonstrably arise from the neural crest, are the precursors of all the endocrine polypeptide cells of the adult pancreas, stomach, duodenum, and small and large intestine, is not at present available. Notwithstanding a great deal of earlier evidence to the contrary, the premise seems likely to be true.

Three types of method have been used for tracing the cells of the neural crest from their origin to intermediate and final destinations. The first of these depends on the employment of 'hot' homografts (radioactive labelling, autoradiography), the second on the technique of heterospecific grafting (allografts), and the third on induced amine formation and storage. In cells possessing the cytochemical characteristics described as APUD (Amine Precursor Uptake and Decarboxylation) included amines can be demonstrated by formaldehydeinduced fluorescence (FIF, Eränkö, 1967), and the whole process can therefore be described as APUDFIF.

The first approach was used by Johnston (1966), who introduced a radioactive marker (tritiated thymidine) into the nuclei of an early chick embryo before transplanting the region containing the cranial neural crest into another embryo. The labelled cells moved rapidly in a ventrad direction and Johnson concluded that they gave rise, inter alia, to the chondrocytes of the visceral arch cartilages.

Received for publication 27 July 1971.
The second approach, employed by Le Douarin and Le Lièvre (1970), involved transplantation of the neural tube region from 7-10-somite Japanese quail embryos into coeval embryos of the domestic fowl. Quail cells can be distinguished from those of the fowl by their possession of a large central chromatin mass. Following transplantation and further incubation it was possible to demonstrate the participation of grafted quail cells in the formation of the ultimobranchial body in the chick. The authors concluded that the $\mathrm{C}$ cells of this organ were of neuroectodermal origin.

The third approach (APUD-FIF) was used by Pearse and Carvalheira (1967) to demonstrate that the calcitonin-secreting $\mathrm{C}$ cells of the mammalian thyroid gland entered that organ with the ventral (ultimobranchial) component of the last pharyngeal pouch. Since their studies, carried out on mouse embryos, extended from the 10th (now recognized to have been the 12th) day of gestation onwards, they noted that possibly the true origin of the $C$ cells was 'outside the pharyngeal pouches'. It had been suggested (Pearse, 1966a and b) that $C$ cells, and 
other endocrine polypeptide-secreting cells subsequently included in the APUD series (Pearse, 1968), arose from the neural crest. This hypothesis was not original. A neural crest origin for the $\mathrm{C}$ cells was implied by the work of Sunder-Plassmann (1939) and Danisch (1924) had made a similar postulate for intestinal enterochromaffin cells. Moreover the endocrine cells of the adrenal medulla, and the melanocytes, which had been shown to belong to the APUD series, are universally accepted as neural crest derivatives.

A pilot study, using chick embryos, was carried out by Polak, Rost, and Pearse (1971) and this indicated that the cells of the neural crest possess APUD characteristics as early as 72 hours. A similar study of early stages of development in the mouse embryo (Pearse and Polak, 1971) had shown that the developing ultimobranchial pouch was colonized, at the 10-somite stage (nine-10 days) by cells from the neural crest, confirming the findings of Le Douarin and Le Lièvre (1970). It was therefore decided to extend the work to cover the development of the gastrointestinal tract and pancreas.

\section{Material and Methods}

Seventy-eight embryos from 10 pregnant albino mice were studied and the age of each litter was calculated either from a witnessed mating or by comparison with previous litters. Where possible the number of somites was counted. The period of gestation extended from the seventh to the 12th day.

The pregnant mice received a single intraperitoneal injection of L-DOPA $(100 \mathrm{mg} / \mathrm{kg})$ and all were killed one hour later. Control embryos from uninjected mothers were provided from a series previously studied.

Immediately after removal the embryos were quenched by immersion in melting Arcton (Freon) 22 and freeze-dried in a thermoelectric tissue dryer at $-40^{\circ}$ for 16 hours (overnight). Subsequently the dried embryos were exposed to formaldehyde vapour at $60^{\circ}$ or $80^{\circ}$ for four hours. All were then embedded in paraffin wax, careful attention being paid to their orientation so as to provide serial $(5 \mu \mathrm{m})$ transverse sections. After cutting, the latter were placed on prewarmed slides, directly from the knife, and mounted in Styrolite.

Fluorescence microscopy was carried out using a Zeiss (Oberkochen) standard universal microscope with an HBO 200 lamp, BG12 and BG38 excitation filters, and a $\mathrm{K} 530$ barrier filter $(50 \%$ transmission at about $530 \mathrm{~nm}$ ).

Every third section was stained with haematoxylin and eosin in order to facilitate identification of structures seen in the fluorescence microscope.
Photomicrographs were taken on Ilford FP4 (fluorescence) or Pan F films.

\section{Results}

At the earliest stages of investigation (seven to eight days) the developing pharynx was readily identified (Fig. 1) together with various pouches, the last of which becomes the ultimobranchial body. Groups of labelled (APUD) cells, travelling down as the central stream of the neural crest, traverse the mesenchymal mass between the neural tube and pharynx (Fig. 2) though they are not detectable in conventionally stained preparations.

At a slightly later stage (10 somites) we observed colonization of the IVth pouch and the wall of the pharyngeal tube by cells from the neural crest, as previously reported by Pearse and Polak (1971). This process is shown in Fig. 3, where the degree of colonization is observed to be particularly intense in both anterior and posterior walls of the pharynx.

Close examination of serial sections of the developing foregut of 8-9-day embryos revealed an epithelium-lined pouch springing from the dorsal wall of the duodenum. This is clearly illustrated and described by Wessells and Rutter (1969) as the dorsal pancreas. Our APUD-FIF sections showed colonization of the gut wall (future stomach and duodenum) by fluorescent neural crest cells and invasion also of the presumptive dorsal pancreas. These processes are illustrated in Fig. 4 where the fluorescent cells can be seen in the mesenchyme which is condensing around the duodenal pouch, as well as in the wall of the foregut. Because the developing acinar cells can be recognized clearly at the 10th day on account of their (transient) uptake of L-DOPA, and because the dorsal pouch of the duodenum in our serial sections showed no such uptake, the possibility exists that it represents the anlage of the common duct and gallbladder rather than of the pancreas. On balance the latter is still the more likely of the two interpretations.

At a later stage of development (10-11 days) the wall of the definitive stomach as well as that of the duodenum (Fig. 5) contained numerous fluorescent APUD cells. Most of these still occupied the basal layers of the epithelium but many already possessed long processes extending towards the lumen. The developing pancreas at this stage (10-11 days) is shown in Figure 6. Dorsal and ventral pancreas now consist of isolated groups of developing acini, ducts, and islets. Brightly fluorescent APUD cells are visible, mainly in areas where the structure of the epithelial cells is duct-like. Some fluorescence is visible in the presumptive acinar tissue. As observed by Alm, Ehinger, and Flack (1969), acinar cells can 


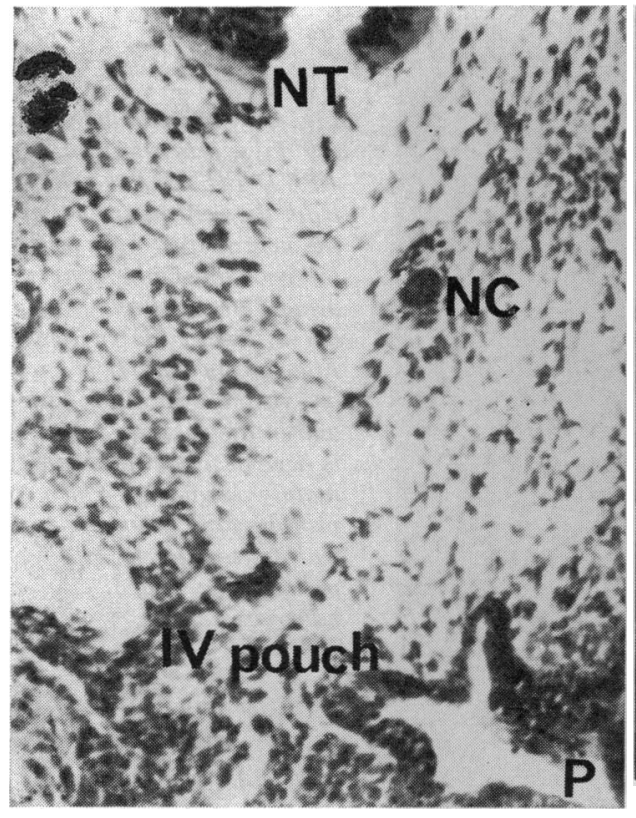

Fig. 1 Mouse embryo, 7-8 days. Freeze-dried, formaldehyde vapour-fixed. Shows the developing pharynx $(P)$ at the level of the IVth pharyngeal pouch. The relationships of the neural tube (NT), notochord $(N C)$, and pharynx are shown, as is the mesenchymal mass lying on either side of the mid-line. Haematoxylin and eosin. $\times 140$.

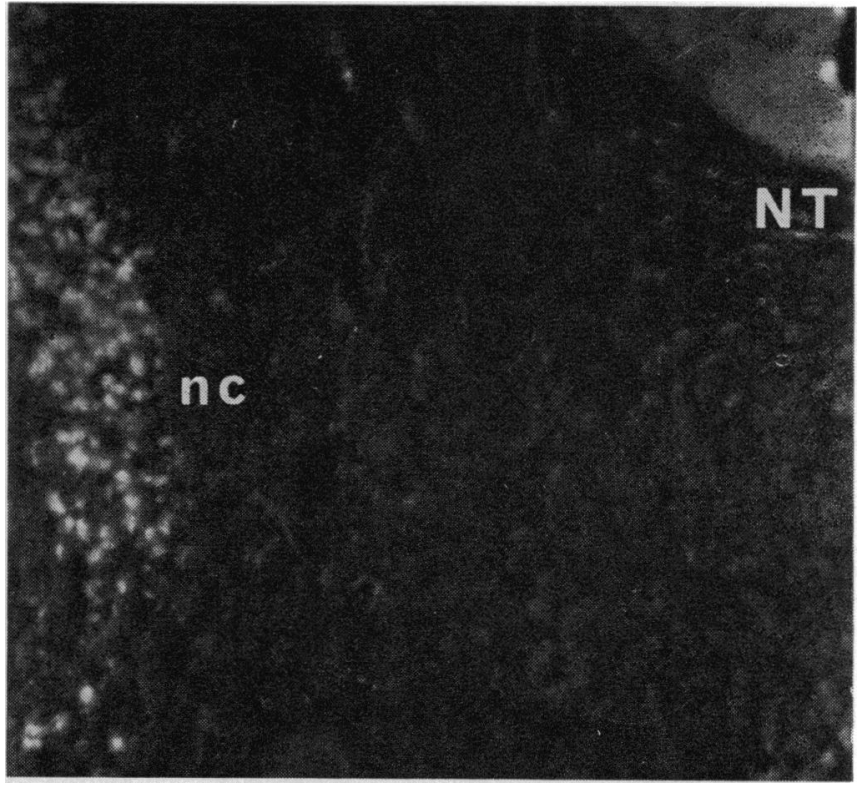

Fig. 2 As Figure 1. Shows a long stream of fluorescent APUD-FIF labelled cells. These are definitive neural crest cells (nc) travelling ventrad from their origin at the epithelio-neural junction. Part of the neural tube (NT) is visible at upper right. $\times 140$.

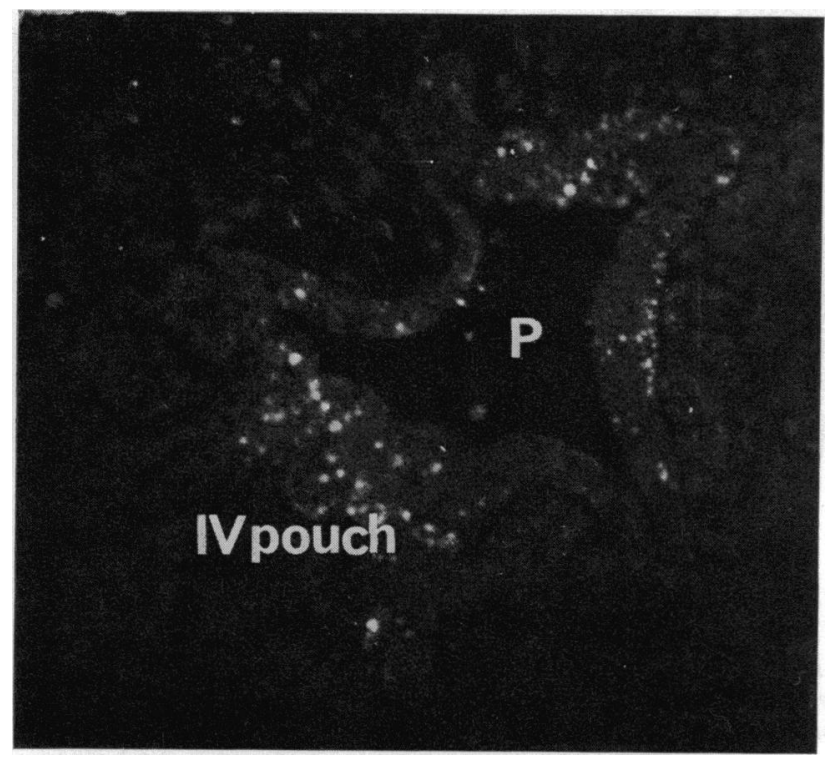

Fig. 3 Mouse embryo, 9-10 days. Freezedried, formaldehyde vapour-fixed, examined by fluorescence microscopy. APUD-FIFlabelled cells from the neural crest have invaded the pharynx $(P)$, particularly on its anterior and posterior aspects. The region of the IVth pouch is labelled. $\times 290$. 


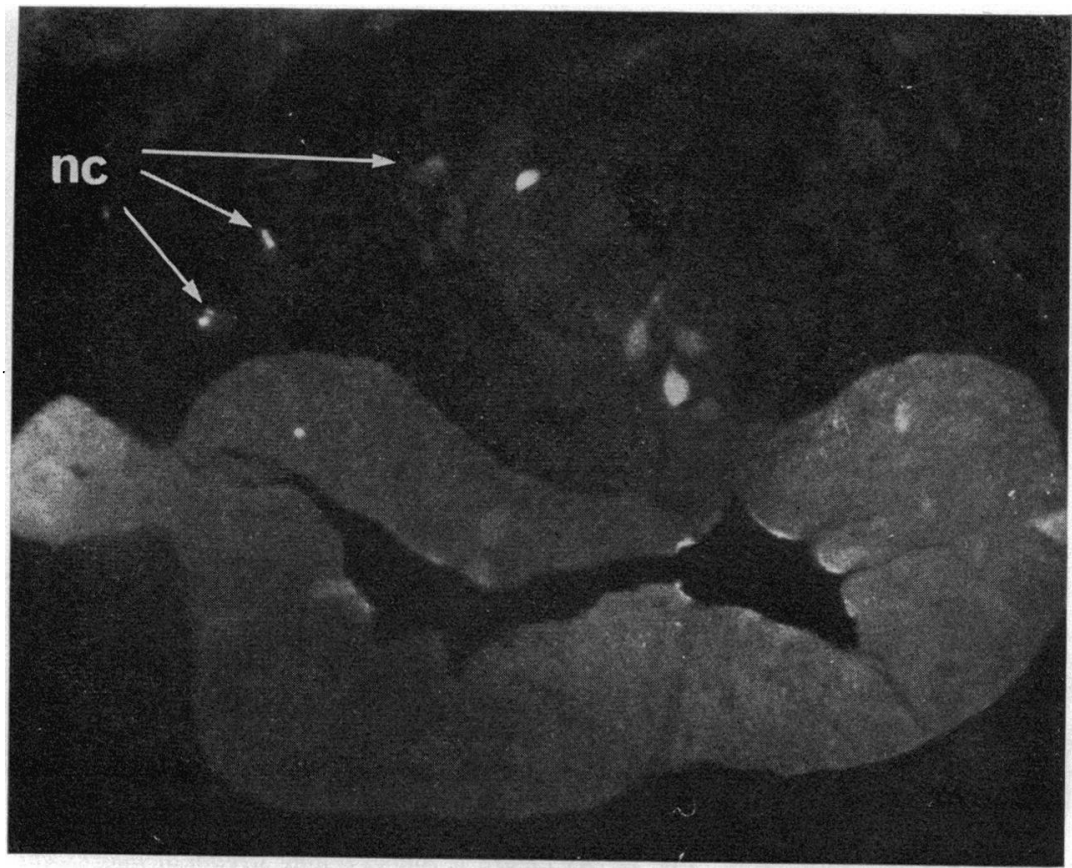

Fig. 4 Mouse embryo, 8-9 days, processed for APUD-FIF. Shows cells from the central stream of the neural crest $(n c)$, in the mesenchyme condensing around the (presumptive) dorsal pancreatic rudiment. Fluorescent APUD cells are visible also in the latter and in the foregut, which is here destined to become mainly duodenum. The protuberance from the gut wall (extreme left) is possibly the ventral pancreas. $\times 340$.

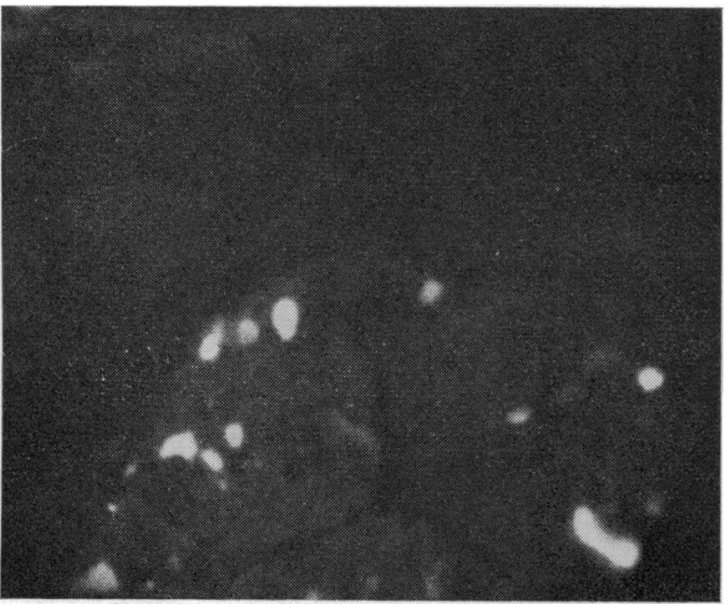

Fig. 5

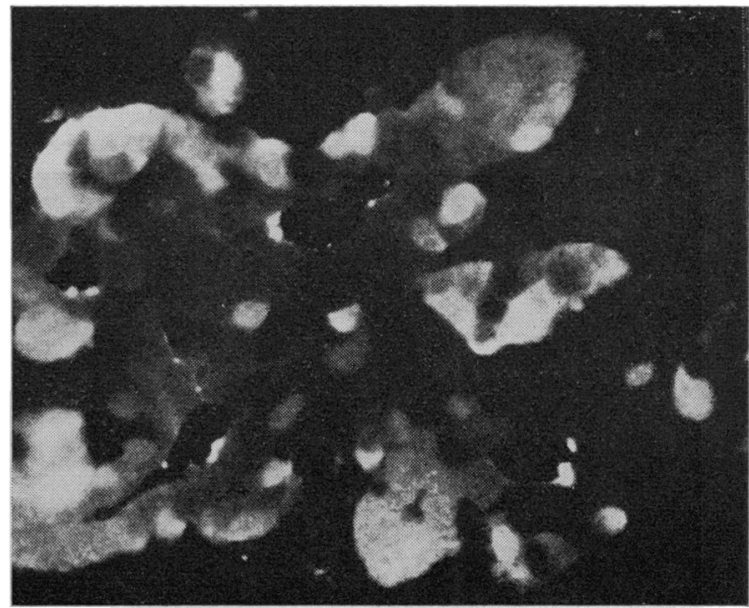

Fig. 6

Fig. 5 Mouse embryo, 11-12 days, processed for APUD-FIF. The definitive duodenum contains many labelled cells and these are not confined to the basal layers. $\times 400$.

Fig. 6 Mouse embryo, 11-12 days, processed for APUD-FIF. The developing pancreas now consists of cords of presumptive acinar cells, here showing moderate fluorescence, from which duct-like structures are arising. The labelled endocrine cells are mainly, if not exclusively, associated with 'ducts'. $\times 400$. 
take up and decarboxylate DOPA. They do not, however, possess the amine-storage mechanism characteristic of endocrine polypeptide cells from which they can thus be distinguished by rapid loss of the label. Proliferating cells of many different types are observed to take up the amino-acid precursors of fluorogenic amines. These are rapidly metabolized, possibly without decarboxylation. Storage is minimal and prolonging the postadministration period of the precursor provides clear differentiation of high protein turnover cells from APUD cells.

\section{Discussion}

The APUD characteristics of the neural crest cells which enable them to be traced effectively over an embryologically long period of time are, in effect, precisely those emphasized by Willmer (1951) when he noted that 'the cells of the neural crest, and its immediate neighbours, seem to have made a corner in a special form of tyrosine metabolism which may culminate either in the formation of melanin or adrenaline'. It is fortunate for us that they have retained this ancestral habit through 300 million years or so of development. Our findings indicate clearly that invading cells from the central, and perhaps from the peripheral, stream of the neural crest colonize the foregut and its derivatives, the most important of which is certainly the pancreas. Concomitant studies have shown that the trachea and primary bronchi are also invaded. The conclusion of Le Douarin and Le Lièvre (1970) that 'les APUD cells de Pearse ont une origine embryologique ectodermique' is thus almost certainly correct, though marginally premature. What cannot yet be determined is whether all the endocrine polypeptide cells of the adult gastrointestinal tract and pancreas are descendants of neural crest APUD cells or whether some are derived by differentiation from the epithelial cells of the gut and pancreatic ducts, as is usually presumed. A list of the endocrine polypeptide cells of the stomach and intestine, modified from the original Wiesbaden list (Creutzfeldt, Gregory, Grossman, and Pearse, 1970), is given in the Table.

It is comparatively easy to imagine environmental differences modifying an originally single cell type so that, for instance, the thyroid or ultimobranchial C cell produces calcitonin while the pyloric $\mathbf{G}$ cell produces gastrin. It is less easy to see how cells of a single type sharing the same environment are modified to produce a number of different hormones even if, as is often the case, their primary structures contain identical amino-acid sequences. Differences in innervation offer a possible solution.

\begin{tabular}{|c|c|c|c|}
\hline \multicolumn{2}{|c|}{$\begin{array}{l}\text { Wiesbaden } \\
\text { Nomenclature }\end{array}$} & $\begin{array}{l}\text { Equivalent Cell } \\
\text { in Pancreas }\end{array}$ & $\begin{array}{l}\text { Product or } \\
\text { Possible Product }\end{array}$ \\
\hline & G & Not known & Gastrin \\
\hline $\mathbf{T}$ & D & D & (Enterogastrone) $^{1}$ \\
\hline $\mathbf{M}$ & ECL & Not present & 一 \\
\hline C & $\mathbf{A}$ & $\mathbf{A}$ & Enteroglucagon \\
\hline & EC & EC & - \\
\hline $\mathbf{N}$ & L & $\mathbf{A}$ & Enteroglucagon \\
\hline $\mathbf{E}$ & $\mathbf{s}$ & Not present & Secretin \\
\hline $\mathbf{T}$ & $\mathbf{x}$ & D & (CCK-PZ) \\
\hline $\begin{array}{l}\mathbf{N} \\
\mathbf{E}\end{array}$ & EC & EC & - \\
\hline
\end{tabular}

Table Endocrine polypeptide (APUD) cells of the gastrointestinal tract

'Possible product is enclosed in brackets.

A number of discrepancies remain to be explained, particularly those relating to the development of the islets. The current view, held almost since their original discovery, is that they arise by budding from the pancreatic ducts. It will clearly be necessary to trace back the definitive endocrine cell types of the adult gastrointestinal tract and pancreas to their earliest forms, using immunofluorescence, electron microscopy, and immunoelectron cytochemistry. While these methods probably offer no quick solution to the problem, the concept of an ancestral relationship between all the polypeptide hormone-producing cells of the foregut and its derivatives may provide reasons for relationships between individual cell types which are otherwise difficult to understand. The APUD cells appear to be brothers, under the skin, and it is perhaps not surprising that they appear to recognize, and to respond to each others' products.

This work was carried out with the help of a grant from the Wellcome Trust. We are grateful to Caroline Maunder for assistance with the dissection of the embryos.

\section{References}

Alm, P., Ehinger, B., and Falck, B. (1969). Histochemical studies on the metabolism of L-DOPA and some related substances in the exocrine pancreas. Acta physiol. scand., 76, 106-120.

Eränkö, O. (1967). The practical histochemical demonstration of catecholamines by formaldehyde-induced fluorescence. J. roy. microsc. Soc., 87, 259-276.

Danisch, F. (1924). Zür histogenese der sogenannten Appendixkarzinoide. Beitr. path. Anat., 72, 687-709.

Johnston, M. C. (1966). A radioautographic study of the migration and fate of cranial neural crest cells in the chick embryo. Anat. Rec., 156, 143-155.

Le Douarin, N., and Le Lièvre, C. (1970). Démonstration de l'origine neural des cellules à calcitonine du corps ultimobranchial chez l'embryon du poulet. C.R. Acad. Sci. (Paris), D., 270, 2857. 2860. 
Pearse, A. G. E. (1966a). 5-Hydroxytryptophan uptake by dog thyroid $\mathrm{C}$ cells and its possible significance in polypeptide hormone production. Nature (Lond.), 211, 598-600.

Pearse, A. G. E. (1966b). Common cytochemical properties of cells producing polypeptide hormones, with particular reference to calcitonin and the thyroid C cells. Vet. Rec., 79, 587-590.

Pearse, A. G. E. (1968). Common cytochemical and ultrastructura characteristics of cells producing polypeptide hormones (the APUD series) and their relevance to thyroid and ultimobranchial C cells and calcitonin. Proc. roy. Soc. B., 170, 71-80.

Pearse, A. G. E., and Carvalheira, A. F. (1967). Cytochemical evidence for an ultimobrandrial origin of rodent thyroid $\mathrm{C}$ cells. Nature (Lond.), 214, 929-930.
Pearse, A. G. E., and Polak, Julia M. (1971). Cytochemical evidence for the neural crest origin of mammalian C cells. Histochemie, 27, 96-102.

Polak, J. M., Rost, F. W, D., and Pearse, A. G. E. (1971). Fluorogenic amine tracing of neural crest derivatives forming the adrenal medulla. Gen. comp. Endocr., 16, 132-136.

Sunder-Plassmann, P. (1939). Uber neuro-hormonale Zellen des Vagussystems in der Schilddrüse. Dtsch.Z.Chir., 252, 210-223.

Wessells, N. K., and Rutter, W. J. (1969). Phases in cell differentiation. Sci. Amer., 220, 36-44.

Willmer, E. N. (1951). Some aspects of evolutionary cytology. In Cytology and Cell Physiology, 2nd ed., edited by G. Bourne, pp. 444-493. Clarendon Press, Oxford. 